DOI: $10.7242 / 2658-705 \mathrm{X} / 2020.3 .8$

УДК 393.05 (=511.1)

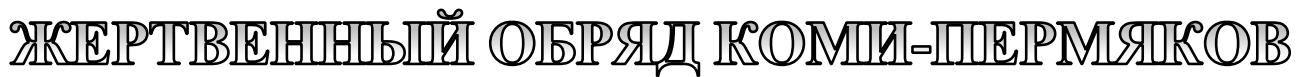 BB CLEJIE IEOMIGIUUARI IROULA *
}

\section{Т.Г. Голева, Пермский федеральный исследовательский центр УрО РАН}

Статья посвящена изучению истории жертвенной традиции комипермяков, которая известна под названием «быкобой» и приурочена ко дню св. Флора и Лавра. Традиция отличалась величиной приносимой жертвы: за один день закалывалось до нескольких десятков животных. Автор уточняет, опираясь на опубликованные материалы, что праздничный комплекс, помимо ритуала жертвоприношения и общей трапезы, включал молебен на реке, окропление лошадей, скачки и ярмарку. Порядок и некоторые условия проведения обряда из года в год менялись. В частности, изменения были связаны с контролем и ограничениями местной власти. Интерес исследователей к необычной традиции обусловил ее известность в более широких кругах. В начале XX В. внимание к обряду стали проявлять представители церкви и общественности. С целью искоренения жертвенных ритуалов духовенство осуществило ряд мер, способствующих просвещению народа. Считается, что перед Первой мировой войной обряд был запрещен. На угасание традиции повлияли последующие исторические события в стране. На рубеже XX-XXI вв. местные жители возродили жертвенный ритуал. Комплекс праздничной обрядности в восстановленном варианте немного отличается от прежней традиции и имеет иное символическое значение. Следствием распространения информации об обряде в наше время стало появление негативных высказываний о ритуале среди общественности, что привело к отказу от его публичного проведения в 2018 г. Как в прошлом, так и в XXI в. обряд жертвоприношения выполнял функцию сплочения народа и обусловил проведение просвещенческих мероприятий.

Ключевые слова: коми-пермяки, жертвоприночение, день св. Флора и Лавра, освящение коней, И.Я. Шестаков, Н.Н. Гусев, возрождение традиции.

Обряд заклания быков в с. Большая Коча Кочевского муниципального округа Пермского края - одна из жертвенных традиций коми-пермяков, которая была возрождена на рубеже XX-XXI вв. Несмотря на то что обряд уже не раз становился объектом описания и изучения (см.: [17, c. 190-196; 31]), некоторые сведения о нем остаются нераскрытыми. В настоящей статье сделана попытка уточнить данные о содержании обряда как комплекса ритуальных действий в течение всего праздника и проследить его историю, определить факторы, повлиявшие на угасание и возрождение традиции. Научное разыскание опирается на описания исследователей и

* Работа выполнена в рамках государственного задания; номер государственной регистрации темы АААA-A19-119032590066-2. 
бытописателей конца XIX - начала

XX вв., газетные заметки, репортажи и статьи прошлых лет и настоящего времени. Вспомогательными источниками послужили записи полевых материалов, архивные и музейные документы.

\section{Обряд в с. Большая Коча} как своеобразная традиция

Обряд жертвоприношения в Большой Коче проводился в день памяти св. Флора и Лавра (31.08; 18.08 - по старому стилю). Этот праздник был хорошо известен комипермякам. На территории Коми-Пермяцкого округа его праздновали как престольный или почитаемый день в д. Бутылевой, д. Таранино, д. Юньге, с. Ленинске, д. Мелехиной, с. Белоево, д. Подъячево, д. Новожилово, д. Панино, д. Большая Половина $[20$, с. $691 ; 41$, c. $251 ; 54$, c. $125 ; 43$, c. 79$]$. Жертвенные ритуалы коми-пермяки приурочивали к разным датам православного календаря [36, с. 25-26; 41, с. 252]. Известно, что жертвоприношение в день Флора и Лавра кроме Большой Кочи осуществлялось еще в д. Паниной и, вероятно, в д. Большая Половина Юрлинской волости, в которой проживало русское население. И.Н. Смирнов указывает, что в д. Половину приводили баранов [41, с. 252]. Жертвенные обряды у других народов Севера России проходили обычно в иные даты православного календаря $[1$, с. $35-36$; 4 , c. $323-324 ; 18$, с. $10-22 ; 25$, с. $214-222$; 48, с. 63-64], день Флора и Лавра в связи с этим упоминается редко [42].

Подробных данных о традициях деревень Паниной и Большая Половина нет, тогда как обряд Большой Кочи был описан в ряде публикаций. Интерес к обряду в прошлом был обусловлен масштабом приносимой жертвы. Нигде более комипермяки не закалывали в честь святых такое число крупного рогатого скота. Еще одной особенностью его можно назвать то, что животных приводили даже из отдаленных населенных пунктов, что было редкостью при проведении других жертвенных обрядов. Известно лишь, что из отдаленных мест для пожертвования при- водили еще баранов в Гайны [20, с. 311]. Причиной приношения жертвы была вера в покровительство святых животноводству и крестьянскому хозяйству, вера в кару за нарушение обычаев (мыља).

\section{Обычаи и ритуалы дня св. Флора и Лавра в Большой Коче в конце XIX - начале XX в.}

Праздник в честь св. Фрола и Лавра (Проллавер - местное название) в Большой Коче в прошлом включал ряд ритуалов, очередность которых зависела от дня недели, на который он приходился. Если это был скоромный день, то жертву приносили накануне. В данном случае вечером проходила короткая служба в часовне, после колокольного звона начинался забой животных. Туши делили, часть мяса варили в двух котлах, поздно вечером или ночью начиналась трапеза. На следующее утро проходили крестный ход и молебен у реки. Во время молебна всадники на лошадях и пешие стояли в воде. При выходе из воды на помосте животных окроплял священник $[23 ; 37]$. В более ранние годы после стояния в воде начинались скачки, которые впоследствии были запрещены, так как однажды во время гонок затоптали человека $[41$, с. 251$]$. Скачки не описывает ни один из очевидцев, видимо запрет был введен до 1880 г. Недалеко от часовни проходила ярмарка, на которую приезжали покупатели и торговцы из соседних волостей. На ярмарку привозили мануфактурные, кожевенные, скобяные, бакалейные товары и съестные припасы [9].

После окончания ритуальных действий начиналось гуляние народа. Если праздник приходился на не постный день, тогда все ритуалы совершались в течение одного дня: с утра пришедшие ставили в часовне свечи, на реке проходила служба с освящением в воде, после нее приступали к закланию быков и приготовлению трапезы [50]. Скорее всего, при посещении часовни участники обряда совершали описанные И. Шестаковым действия по отношению к почитаемому резному образу Спасителя: целовали его руку, терли глаза 
фатой, которая его покрывала [50, с. 34]. М.В. Малахов отмечает, что «...ко Христу делали частые приклады холстом» $[23$, с. 90]. Данные ритуальные действия, вероятно, совершались с целью избавления от болезней (мыља), именно так интерпретируются старожилами приклады к иконам в настоящее время [6, с. 43$].$

Отметим, что обычай стоять в водоеме с лошадьми и без лошадей во время молебнов был широко распространен у комипермяков и приурочен к разным православным датам [7]. В Большой Коче данному ритуальному действию придавалось особое значение еще и потому, что святые Флор и Лавр считаются покровителями лошадей. Обычаи освящения и купания коней также известны в традициях народов Русского Севера и русских Пермской губернии [4, c. $280-283 ; 22$, с. $452 ; 49$, с. $258-262]$. Гонку на лошадях в день Флора и Лавра еще в начале XX в. коми-пермяки продолжали устраивать в д. Бутылевой [54, с. 127]. Кроме того, скакали верхом на конях в Крещение [33]; иньвенские коми-пермяки таким образом изгоняли, «топтали» святочных чудов [5, с. 54]. По словам В.М. Яновича, лошадь стараются во время гонок вогнать в пот, так как это «признак всосания воды в кровь лошади» [54, с. 127]. То есть скачки считались своеобразным катализатором акта освящения коней. Также автор отмечает, что во время скачки хозяева показывали способности коня, чтобы затем можно было выгодно его продать.

В русской традиции скачки на лошадях в дни праздников устраивали в специальных местах. С.В. Максимов считает, что это были места древних игрищ, на которых уже позднее появились часовни [22, с. 452-453]. Примечательно, что у карел конские ристалища были приурочены ко дню проведения жертвоприношения, как и у коми-пермяков в Большой Коче. У карел победитель скачек получал особый статус в местном сообществе [18, c. 17-21]. Таким образом, скачки в народной культуре можно рассматривать как турнир наездников, демонстрацию будущего товара и как часть обрядового ком- плекса. В целом обрядность дня Флора и Лавра в Большой Коче была универсальной для праздничной традиции коми-пермяков и имела общие черты с православными обычаями других народов.

Собственно жертвоприношение, по имеющимся описаниям, было слабо регламентировано народными обычаями. Известно, что в жертву старались принести трехгодовалого непорочного бычка [23]. По другой версии, обещали пожертвовать страдающее от недуга животное в случае его выздоровления [41, с. 251]. Перед праздником следовало помыться в бане; хозяин вел животное с непокрытой головой; убивали быка ударом ножа по горлу; условным знаком начала забоя животных и трапезы был колокольный звон [23; 50]. По сведениям М.В. Малахова, которые относятся к началу 1880-х гг., обряд проходил под контролем местной власти и полиции. На празднике присутствовал десятский, в деревню приезжали священник и кто-то из чиновников, скот осматривал ветеринарный фельдшер. Посредником между народом и представителями институтов власти и религии выступал часовенный староста, который исполнял роль организатора [23].

Стоит отметить, что дележ продуктов жертвоприношения очевидцы описывают по-разному. По сведениям М.В. Малахова, в 1880-81 гг. филейную часть отдавали попу, грудинку - нищим, головы посвящали Богу, их хранили в часовенном амбаре. Одна из голов в день праздника была опалена и запечена на костре [23, с. 92]. При В. Сабурове часть жертвенного мяса хозяева увезли с собой, часть - продали и средства оставили часовне [37]. По данным И. Шестакова, голову без языка отдавали сельскому старосте, «более лакомые куски, почки и язык» оставляли для гражданской администрации, в котлах готовили переднюю часть быка, а задняя оставалась причту [50, с. 35$]$. По словам И.Н. Смирнова, священники получали для себя лопатки [41, c. 251]. В.М. Янович пишет, что общее варево готовилось главным образом из ног и голов животных [54, с. 126]. Шкуры жи- 
вотных, по утверждению большинства авторов, продавали в пользу часовни. Таким образом, помимо приготовления жертвенного блюда, части животных поступали в часовню, оставались хозяевам, распределялись между священником, чиновниками, нищими. Благодаря данным описаниям можно констатировать, что особое значение имела голова животного, которая была частью общей трапезы, посвящалась Богу или вручалась часовенному старосте. Нераскрытым остается вопрос о том, как поступали с оставленными в часовенном амбаре головами. Головы животных комипермяки готовили и в другие почитаемые праздники - Василий вечер, Ильин день $[36$, с. $25 ; 41$, с. $253 ; 54$, с. 125$]$. Особое отношение к голове жертвенного животного отмечается также в обычаях карел и удмуртов $[18$, с. $12-13 ; 38$, с. $45 ; 53$, с. 47,119$]$. Предположительно, эта традиция у финноугорских народов имеет древние корни.

Местом заклания животных при М.В. Малахове был участок к северу от часовни, включающий вспаханное поле. Часовня в Большой Коче стояла на высоком берегу р. Оноловы, в восточной части от нее располагались дома и огороды [23]. В. Сабуров местом жертвоприношения называет поле площадью до 2 десятин в 50-60 саженях от деревни [37]. И. Я. Кривощеков пишет о том, что место заклания в разные годы менялось, от часовни его переносили ближе к мельнице, позднее убой происходил за чертой селе-

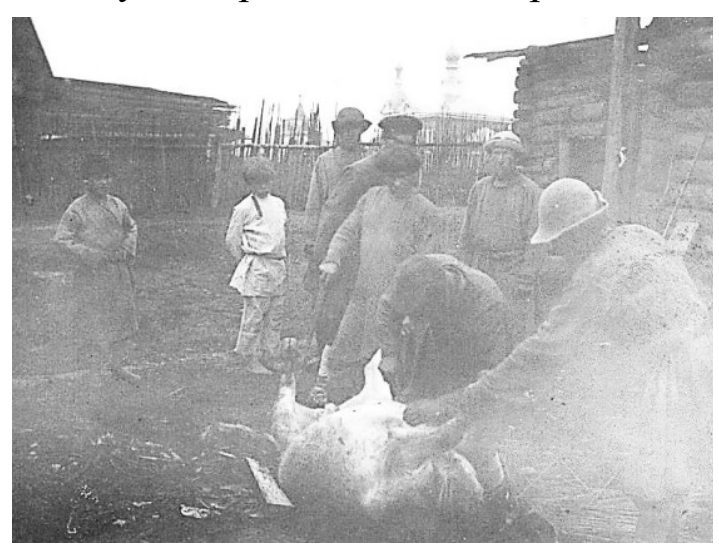

Фото 1. Заклание быка в Большой Коче. 1911 г. Автор К.М. Мошегов.

Чердынский краеведческий музей. Фонд фотодокументов, Д. 1644/5. ния [20, с. 226]. Действительно, на фотографиях места заклания отличаются. На фото 1911 г. действие происходит рядом с постройками, за оградой виднеются крыши церкви и часовни (см. фото 1). На другом снимке быков разделывают вблизи огороженного поля и леса (см. фото 2).

Место молебна и стояния в реке во время праздника 1908 г. можно увидеть на фотографиях В.А. Плотникова $[46$, с. 151$]$. Во время молебна люди находились на высоком склоне берега недалеко от построек, а некоторые стояли в воде [27]. Ниже по течению реки располагался мост. Небольшой участок реки рядом с берегом был огорожен (примерно $2 \times 2$ м), в данном месте стояла кадушка для освящения воды. Рядом с двумя дальними углами участка в реке стояли молодые ели [28]. В момент фиксации снимка по периметру огороженного места находились мальчики-подростки. Фотографии свидетельствуют об участии в молебне большого числа людей. Как и при забое животных, на нем присутствуют мужчины, женщины и дети (см. фото 2, 3).

Думаем, что некоторые женщины и дети не просто наблюдали за забоем, а помогали мужчинам. Так, М.В. Малахов пишет, что дети внимательно следили «за всем совершаемым окрест их», а также они подтаскивали и раскладывали солому, на которую клали тушу животного $[23$, с. 91-92]. На одном из снимков вид-

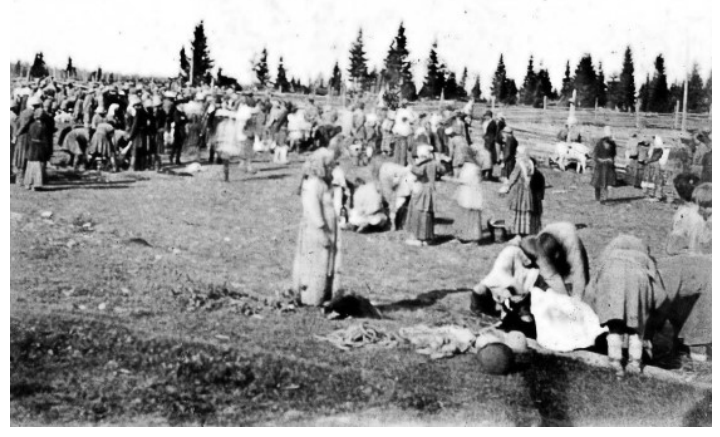

Фото 2. Жертвоприношение в Большой Коче. Автор неизвестен. Чердынский краеведческий музей. Фонд фотодокументов, Д. 1644/4. 


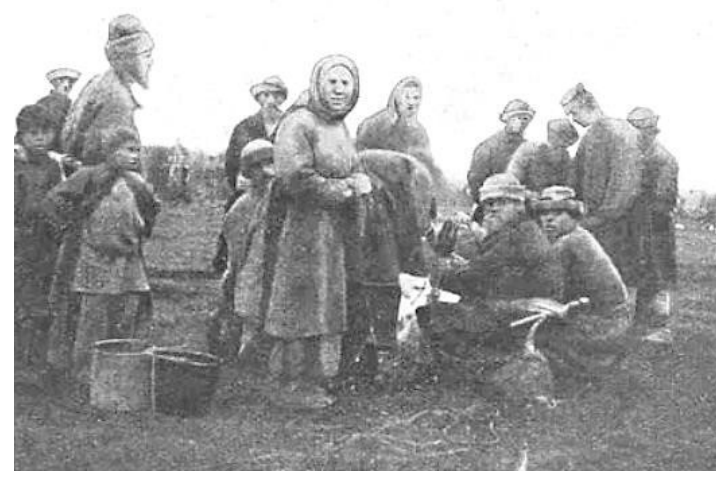

Фото 3. Жертвоприночение в Большой Коче 1908 г. Автор: В.А. Плотников. Фото из публикации Шестакова Я. Жертвоприночение пермяков-христиан в день Флора и Лавра.

но, что люди, не задействованные в разделке туш, стоят по краям площадки, видимо, ожидая трапезы (см. фото 2).

Каждый год в Большую Кочу приводили разное количество быков. Его увеличение И.Я. Кривощеков объясняет тем, что возросло народонаселение и число населенных пунктов [20, с. 225]. И.Н. Смирнов пишет, что в 1870-е гг. закалывали до 80 голов; А. Крупкин сообщает, что за ночь резали от 70 до 100 животных; В.М. Янович - «до 50 штук быков и множество баранов» $[21$, с. $306 ; 41$, с. $251 ; 54$, с. 126]. Данные сведения, как мы полагаем, были известны из устных сообщений и, возможно, были преувеличены. С большей уверенностью мы можем полагаться на свидетельства очевидцев. При М.В. Малахове в 1880 и 1881 г. было зарезано 22 и 25 животных; В. Сабуров в конце $1890-x$ г. насчитал до 20 животных $[14$, с. $51 ; 23$, с. 96 ; 37, с. 2]. И.В. Шестаков дает цифры за несколько лет: в 1908 г. было заколото 45 быков (или 47-48), в 1909 - 35, в 1910 - 25 и в 1911 - 1 бык [50, с. 33; 51, с. 1 ; 52, с. 4]. Косвенным подтверждением сведений о 1911 г. может быть фотография К.М. Мошегова, на которой запечатлен забой одного животного (см. Фото 1).

К истории обряда: причины угасания и возрождения

Впервые обряд упоминается в отчете об экспедиции М.В. Малахова 1881 г. [32, с. 38]. М.В. Малахов побывал в Большой Коче дважды - в 1880 и 1881 гг. [47, с. 173]. В 1888 г. вышли его посмертные записки об обряде. Публикация вызвала интерес у исследователей, а затем и широкой общественности к теме жертвенных традиций коми-пермяков, что в определенной степени повлияло на последующую историю обряда.

Многие авторы публикаций рубежа $\mathrm{XIX-XX}$ в. пишут о введении запретов на проведение жертвоприношения. По данным И.Я. Кривощекова, еще в 1860-х гг. местная полиция стала преследовать обычай из-за большого числа приносимых в жертву животных: «...стеснения привели к уменьшению числа жертвенных быков, которых закалывалось 4-5 штуки в год; с этим совпали года неурожая, стеснения были ослаблены» [20, с. 226]. Другие авторы отмечают «преследование» «народного торжества» и предприятие ряда мер к его искоренению в начале XX в. гражданским начальством, так как в обычае оно видело «одно из средств, ведущих к обеднению населения» $[12$, с. 416 ; 21, с. 306]. В 1903 г. В.М. Янович пишет, что «С прошлого года [возможно, с 1902 г. или ранее - Т.Г.] власть не духовная, а административная запретила празднование в Коче. Праздник перенесли в ближайшую деревеньку Соликамского уезда» [54, с. 125]. Известно, что обряд в Коче проводился и после 1903 г., и никто из авторов о переносе больше не упоминает. В.М. Янович сам наблюдал освящение коней и скачки в д. Бутылевой в день Флора и Лавра, но жертвенные ритуалы там не осуществлялись. Таким образом, большинство авторов отмечают введение ограничений местной администрацией. Главным мотивом для запретов являлось чрезмерное, неоправданное число приносимых в жертву животных, что сказывалось на благосостоянии народа.

В начале XX в. определенные усилия к искоренению обряда начинает предпринимать духовенство. Особенно можно выделить деятельность священника Иакова Шестакова. По его инициативе с 1904 г. в Большой Коче начала основы- 
ваться Иоано-Серафимовская инородческо-пермяцкая женская обитель [44, с. 119-120]. Сам И. Шестаков о предполагаемых просвещенческих результатах этой миссии писал следующее: «Как с открытием Пешнигортской женской обители среди инородцев Соликамского уезда исчез обычай приносить в храм бараньи головы, так и в Коче с обителью исчезнет обычай закалывания быков» [51, с. 3]. И. Шестаков придавал большое значение женскому образованию, так как женщины занимались воспитанием детей в семье [51, с. 3]. В 1913 г. в устроенном монастыре проживало уже 50 человек, в том числе немало послушниц из комипермяцких деревень [8]. В 1907 г. в Большой Коче была построена церковь, в 1910 г. при монастыре открыта школа грамоты и рукоделий [44, с. 120]. В 1914 прошел крестный ход из Перми до Большой Кочи с участием инокинь местной обители, в 1915 г. - из Белогорского монастыря до Спасского мужского общежития с посещением Большой Кочи [19; 29]. Религиозные шествия должны были обратить на себя внимание коми-пермяков, показать ритуалы, одобряемые церковью.

Именно о похожих мерах к просвещению народа говорилось на миссионерском съезде духовенства II Чердынского округа осенью 1915 г. в с. Кочево, который прошел под председательством епархиального миссионера А. Куляшова. Целью съезда было «выяснить религиозно-нравственное состояние пермяцкого населения и выработать меры к поднятию и обновлению церковной и религиознонравственной жизни пермяка» [16]. По итогам съезда местным священникам предлагалось устраивать торжественные церковные празднества, паломничества, крестохождения с проповедью на русском и коми-пермяцком языках. Съезд не случайно проходил недалеко от Большой Кочи: помимо того что рядом с селом Кочево к тому времени находились две монашеские обители, место его проведения указывает на имеющиеся здесь проблемы. Мотивом для описанной активной деятельности церкви являлись духовно-религиозные воззрения крестьян, которые выражались в народных обычаях. В отличие от гражданских властей, духовенство действовало более мягко. Предпринятые меры способствовали развитию грамотности и ремесла среди местного населения, формированию связей села с православными центрами.

Помимо местных властей и церкви, на обряд обратила внимание интеллигенция: художник В.А. Плотников, учитель К.М. Мошегов, которые оставили фотоснимки обряда. В начале 1911 г. в пермской газете появилась критическая заметка о жертвенном обряде коми-пермяков, автором которой был бывший секретарь Л.Н. Толстого Николай Николаевич Гусев, находившийся в это время в ссылке в д. Корепино Чердынского уезда. По словам краеведов Владимира и Тамары Светлаковых, которые в начале 1960-х гг. вели переписку с Н.Н. Гусевым, благодаря его публикациям в разных газетах и подхватившим его мысль другим публицистамписателям «священнослужители, испугавшись огласки и позора, были вынуждены запретить проведение быкобоя» [39]. Н.Н. Гусев называет обряд «варварским», 〈жестоким пиршеством», но основная его критика направлена в адрес служащих церкви: «местное духовенство не только знает этот ужасный обряд, но даже поощряет его, косвенно принимая в нем участие» [10]. Возможно, данная заметка на самом деле инициировала более решительные действия власти и духовенства, так как уже летом 1911 г. в жертву был принесен лишь один бык.

Годом окончательного запрета обряда жители села считают 1914 г. [13; 31, c. 90], причем с неисполнением традиции связывают последовавшее несчастье - начало Первой мировой войны. Журналист Ф. Истомин пишет, что обряд последний раз был осуществлен в 1922 г. [15, с. 1]. Вполне возможно, что в 1920-х гг. отдельные хозяева еще приносили животных в жертву святым. По словам жительницы д. Малая Коча 1928 года рождения, 
она смутно помнит, как на берегу готовили в котлах мясо: Вот токо челядёкнам адззылі, Большой Кочаас лэдзчан, мельницайс вӧлӧм, прудысс мунӧ, пруд велдӧрас.... Сійӧ тӧда мало дело. Вот этатшӥм котёллэзӧн яйсӧ пуисӧ $u$ вердісӧ. Кин баран вайӧ, кинкӧ даже кукань, кин нетель начкылӧма сэтчӧ, и пуллісӧ. < ..> Каждӧйэс вердісӧ, челядь и мый. < ..> Пызаннэс мый вӧлісӧ берег доpac. Кьлдз вӧтӧн ни ме сійӧ тӧда. 'Вот только ребенком видела, в Большую Кочу спустишься, мельница была, пруд, над прудом... Это знаю мало дело. Вот в таких котлах мясо варили и кормили. Кто барана ведет, кто-то даже теленка, кто телочку закалывал тут, и варили. <..> Каждого кормили, и детей. <..> Столы были на берегу. Как во сне я уже это помню' [33]. Сложно сказать, насколько данное сообщение достоверно, так как воспоминания туманные, на них могли повлиять устные рассказы. Другие старожилы повествуют о проведении молебнов на берегу реки либо о раздаче мяса в день праздника: Одзза годдэзас сідз керлісӧ: сія локтас да, быкобойыс, да например ме начкыла, тэ, сія начкылас, и эт ыюжда яй кусӧккесӧ сеталлісӧ отирыслӧ 'В прежние годы так делали: наступит быкобой, и например я заколю, ты, он заколет, и такие куски раздавали людям' [34]. Примеры сохранения обычая умываться на реке и колоть животных дома в день праздника в советские годы приводит также Д. Пантюхин [31, с. 90].

Документов о запрете обряда пока найти не удалось, а старожилы села уже не могут назвать точно, в какие годы животных еще приносили в жертву. Отметим, что в других селениях подобные обряды тоже были утрачены в течение XX в. Причинами их забвения можно назвать сложное экономическое положение в периоды войн и государственных преобразований, а также давление новой идеологии, которое сопровождалось закрытием церквей.

Возрождение обряда в конце XX в. явилось результатом деятельности ряда местных энтузиастов, которые интересо- вались историей и традицией села. В Кочевском районе в 1990-х годах отмечалась поддержка народных праздников со стороны районного отдела культуры. Были проведены «Петровки» с обрядом стояния в воде в д. Зыряново, праздник Троицы в Кукушке, «День смены травы» в Большой Коче. Обряд жертвоприношения, по словам Надежды Николаевны Исаевой, бывшего специалиста районного отдела культуры, стало возможным реконструировать по материалам воспоминаний местных жителей, которые собирал руководитель ансамбля «Мича асыв» Андрей Гагарин, и статьи М.В. Малахова, копию которой привез в село переселенец из Свердловска Н. Трушников [35].

Спонсорскую помощь в организации праздника оказал А.А. Климов, депутат Законодательного Собрания Пермской области, он же помогал при проведении других мероприятий. Для района обряд «быкобой» был одной из местных традиций, которые выражали этнокультурное своеобразие. Стараясь сохранить аутентичность народных обычаев и их сакральное значение для народа, организаторы праздников через демонстрацию ритуальных действий актуализировали традиции для молодых поколений. В отличие от других обрядов, «Быкобой» и «День смены травы» к концу ХХ в. были утрачены, изначально их возрождение являлось конструируемым. Хотя в них принимает участие большая часть местного населения, основными организаторами и исполнителями ритуальных действий являются участники фольклорного коллектива и местные краеведы.

В настоящее время обряд жертвоприношения быка был совершен три раза - 29 августа 1999 г., 27 августа 2000 г., 30 августа 2009 г, всегда в воскресные дни. В разные годы он стал частью празднования 420-летия села, Дня села и фестиваля «Оланвӧлан коми отир». Уже в первые годы праздник посетили гости из соседних районов, Перми и Свердловска. Первый обряд был проведен с участием священнослужителя, в 2000 г. его повторили без священника, так как Пермская епархия на запросы 
организаторов ответила, что проводимое жертвоприношение «не богоугодное дело» [35]. С первого года праздник включал выступления фольклорных коллективов и выставку изделий мастеров $[15$, с. 1]. Сам ритуал состоял из символического освящения животного, его забоя, омовения присутствующих кровавой водой, приготовления мяса и общей трапезы [31]. В возрожденном обряде жертва приносилась с надеждой на общее благосостояние народа [3]. Отметим, что в ранних описаниях обряда нигде не говорится об омовении кровавой водой. Освящение и стояние в воде всегда происходило либо до заклания животного, либо на следующий день. Никаких действий с кровью очевидцами не называется. Кровь, по описаниям, стекала на землю [23, с. 91]. Думаем, нельзя полностью исключать возможность совершения каких-либо действий с кровью животного в прошлом. Известно, например, что летские пермяки (коми) кровью жертвенного барана в Ильин день смазывали лицо [11, с. 579]. В возрожденном варианте праздника два разных ритуала - забой животного и омовение освященной водой - оказались совмещены.

Ритуал планировали осуществить и 31 августа 2018 г. в рамках фестиваля «Проллавер», поддержанного краевой программой «59 фестивалей 59-го региона». В начале лета 2018 г. местный краевед Василий Иванович Гагарин в социальных сетях написал о планах проведения жертвоприношения. Отметим, что уже в 1999 г. организаторы приглашали желающих посетить праздник [3]. После объявления 2018 г. последовали негативные комментарии от пользователей социальных сетей, зооза-

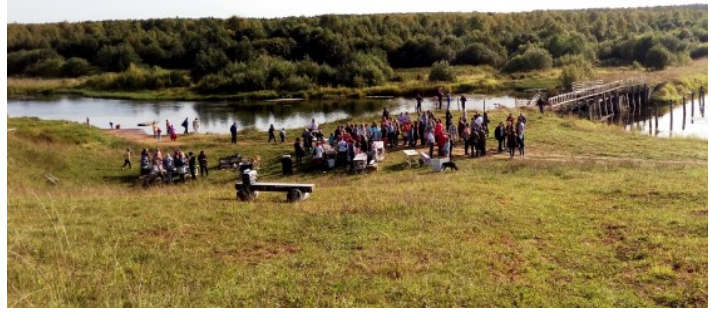

Фото 4. Трапеза на берегу реки, с. Большая Коча, 31 августа 2018 г. щитников, которые были подхвачены СМИ [26; 30]. Позже анонс автором был удален. Похожие критические реплики пользователи рунета оставляли и ранее к публикациям, повествующим об обряде 2009 г. (см. [2]). Граждане оценили народный обычай как жестокий и устаревший, осудили демонстрацию забоя животного и совмещение жертвенного ритуала с мероприятиями развлекательного характера. В итоге в программу фестиваля ритуал с закланием животного не вошел.

Фестиваль 2018 г., кроме традиционных концерта и выставки-ярмарки народных промыслов, включил молебен в часовне, показ документального фильма А.Д. Балуева «Быкобой», экскурсию в школьном музее, игры и угощение народными блюдами в Доме фольклора, круглый стол по теме «Сохранение нематериального культурного наследия. Проблемы и вызовы XXI в.» с участием краеведов, исследователей и педагогов. В числе задач круглого стола было ознакомление «непосвященных» с историей праздника и обычаями коми-пермяков, с целью смягчения негативного отношения к традиции села. В сложившейся ситуации, на наш взгляд, была потребность в открытом обсуждении разных точек зрения о жертвенном ритуале и определении общих позиций, чего, к сожалению, не было на проведенном круглом столе. По завершении основных культурных мероприятий гости направились на берег реки, где в больших котлах была сварена говядина, ею и домашним пивом угощали всех желающих (см. фото 4, 5). Бык был зарезан утром на ферме. В районной газете подаваемое мясо все-таки на-

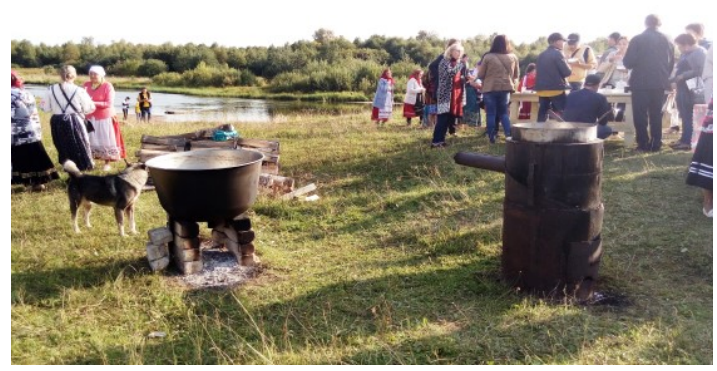

Фото 5. Котль для варки жертвенного мяса, с. Большая Коча. 2018 2. 
звали «жертвенным» [24]. После трапезы на берегу продолжилось гуляние с песнями и хороводами. Праздник посетили гости из разных территорий, а также зоозащитники, исследователи и журналисты. Подробно народное торжество описано в репортажах газет [40; 45].

Отмену заклания животного на берегу реки местные жители восприняли как запрет [39] и как стеснение локальной этнической традиции. Несмотря на то что обряд для современных поколений уже не является привычным явлением, он считается частью культурной жизни села, элементом традиции, которую уважают и почитают.

Обычаи дня св. Флора и Лавра в с. Большая Коча были типичны для комипермяцких календарных обрядов, но проводимое в этот день жертвоприношение выделялось среди прочих числом приносимых в жертву животных. Для комипермяков значение имела не только дата, но и место принесения жертвы. Несмотря на почитание праздника во многих деревнях, животных в этот день закалывали только в трех населенных пунктах. Специфическая характеристика обряда стала причиной внимания к нему исследователей, а после нескольких публикаций - и более широкой публики. Во второй половине XIX в. власти регулярно пытались вводить ограничения, контролировали сам процесс, но население не отказывалось от традиции. Известность обряда в начале XX в. отчасти способствовала тому, что кроме гражданских властей активные меры к просвещению народа начала предпринимать церковь, а затем критически о проблеме отозвались представители общественности, что могло привести к окончательному запрету на проведение жертвоприношения. Угасанию традиции, на наш взгляд, способствовали политическая и экономическая нестабильность в конце 1910-х и последующие годы, закрытие церквей. Постепенно обряд утратил свою актуальность, о нем помни- ли, но не находили причин и возможностей для осуществления, хотя старшее поколение продолжало исполнять некоторые ритуальные акты этого дня.

В конце XX столетия возрождение ритуала имело иное организационное сопровождение. Основной причиной возобновления традиции был поиск этнолокальной идентичности [31, с. 97]. Обряд неизбежно приобрел новые черты, продиктованные условиями сегодняшнего дня. Главное внимание во время праздника уделялось действиям с жертвенным животным, а крестный ход к реке, освящение коней не были восстановлены. Это объясняется тем, что организаторы опирались на описание М.В. Малахова, в котором молебен на реке лишь кратко упомянут. В XXI в. история повторилась: распространение информации о нем спровоцировало появление критических высказываний и привело к отказу от публичного заклания животного. В 2018 г. был проведен новый вариант праздника, который частично удовлетворял разные стороны.

История обряда «быкобой» демонстрирует, что данная традиция в XIX и начале $\mathrm{XX}$ в. была не только выражением этнических верований, но способствовала сплочению народа, формированию связей между разными территориями. Существование обряда обусловило внимание гражданских властей к данной местности, интерес выдающихся личностей прошлого к жизни народа, инициировало просветительскую деятельность, стало причиной основания новых религиозных организаций. В настоящее время возрожденный обряд вновь привлек внимание к селу и обычаям народа, стал поводом для развития межтерриториальной коммуникации. Вместе с тем он вызвал полемику, в которой верность традициям противопоставляется представлениям постиндустриального общества об этичности. Данная ситуация побуждает по-новому рассмотреть вопросы поддержания народных обычаев в XXI в. 


\section{Библиографический список}

1. Бойко Ю.И. Традиционная культура прилузских коми (конец XIX - первая половина XX века) // Известия общества археологии, истории и этнографии при Казанском университете. - 2018. - Т. 38. № 1. - С. 6-191.

2. Быкобой [Электронный ресурс] - URL: https://d3.ru/bykoboi-340616/?sorting=rating (дата обращения: 17.06.2020).

3. «Быкобой»-к празднику // Парма. - 1999. - 18 авг. - С. 3.

4. Винокурова И.Ю. Животные в традиционном мировоззрении вепсов (опыт реконструкции). Петрозаводск: Изд-во ПетрГУ. - 2006. - 448 с.

5. Голева Т.Г. Мифологические персонажи в системе мировоззрения коми-пермяков. - СПб.: Изд-во «Маматов», 2011. - 272 с.

6. Голева Т.Г. Егорьев день в локальных традициях коми-пермяков // Традиционная культура. - 2012. № 1. - C. 37-46.

7. Голева T.Г., Черных A.B. «Стояние на воде» - «Ваын сулавны»- в календарной традиции комипермяков // Проблемы истории, филологии, культуры. - 2009. - №1 (23). - С.544-551.

8. Государственный архив Пермского края. Ф. 198. Оп. 1. Д. 495. Послужные списки монахинь Пешнигортского и Кочинского женского монастыря за 1913 г.

9. Государственный архив Пермского края. Ф.44. Оп. 2. Д. 15. Сведения о ярмарках и базарах в Чердынском уезде.

10. Гусев Н. Власть тьмы // Пермская земская неделя. - 1911. - № 2. - Кол. 28-30.

11. Добротворский Н. Пермяки. Бытовой и этнографический очерк // Вестник Европы. - 1883. - Т. 2. Кн. 4. - С. 548-580.

12. Жаков К.Ф. По Иньве и Косе. Этнографический очерк // Живая старина. - 1903. - Вып. 4. - С. $409-421$.

13. Жданович Е. Быкобой // Парма. - 2000. - 14 сент. - С. 4.

14. Живописная Россия. Отечество наше в его земельном, историческом, племенном, экономическом и бытовом значении. Т. 8: Среднее Поволжье и Приуральский край. Ч. 2. Приуральский край. - СПб., М.: [Тип.] М.О. Вольф, 1901. - 311 с.

15. Истомин Ф. Бычок Богу в душу // Звезда. - 1999. - 2 сентября. - С. 1-2.

16. К миссионерскому съезду в с. Коче Чердынского уезда // Пермские епархиальные ведомости. 1915. - № 36. - С. 1091-1092.

17. Климов В.В., Чагин Г.Н. Круглый год праздников, обрядов и обычаев коми-пермяков. - Кудымкар: Коми-Пермяцкое кн. изд-во, 2005. - 256 с.

18. Конкка А.П. На плечах Большой медведицы. Избранные труды. - Петрозаводск: Карельский научный центр РАН, 2015. - 342 с.

19. Крестные ходы // Пермские епархиальные ведомости. - 1915. - № 17. - С. 559.

20. Кривощеков И.Я. Словарь географическо-статистический Чердынского уезда Пермской губернии. Пермь: Электро-Типография «Труд», 1914. - 839 с.

21. Крупкин A. Верования Пермяков-инородцев // Известия Архангельского общества изучения Русского Севера. - 1911. - № 4. - С. 301-307.

22. Максимов С.В. Нечистая, неведомая и крестная сила. - СПб., 1903. - 529 с.

23. Малахов М.В. Быкобой у пермяков в день Флора и Лавра // Записки Уральского общества любителей естествознания. - Екатеринбург, 1888. - Т. ХІ. - С. 85-96.

24. Минина E. Проллавер [Электронный ресурс] // Кочевская жизнь. - 2018. - № 17. - С. 9. URL: http://kochlib.permculture.ru/.aspx (дата обращения: 10.03.2020).

25. Мороз А.Б. Легенда о жертвенном олене: география, варианты, источники, параллели // Ethnolinguistica Slavica. - М.: Индрик, 2013. - С. 212-233.

26. Морозова О. На празднике в Пермском крае принесут в жертву быка и омоются в его крови с одобрения Минкульта [Электронный ресурс] // Сноб. - 2018. - 3 августа. - URL: https://snob.ru/news/164145 (дата обращения: 21.06.2019).

27. Музей антропологии и этнографии им. Петра Великого. Фотоотпечаток. МАЭ № 1501-10 [Электронный ресурс] // Госкаталог.РФ. - URL: https://goskatalog.ru/portal/\#/collections?id=10877855 (дата обращения: 16.06.2020).

28. Музей антропологии и этнографии им. Петра Великого. Фотоотпечаток. МАЭ № 1501-11 [Электронный ресурс] // Госкаталог.РФ. - URL: https://goskatalog.ru/portal/\#/collections?id=10877840 (дата обращения: 16.06.2020).

29. Мырзин M. Крестный ход в Кочинское монастырское женское общежитие // Пермские епархиальные ведомости. - 1914. - № 25. - С. 474-475.

30. Насадный А. Быкобой против чиновников: деревня язычников борется за обряд, во время которого режут быка [Электронный ресурс] // Неизвестная Россия. - 2018. - 23 августа. URL: https://www.currenttime.tv/a/29445406.html (дата обращения: 16.03.2020). 
31. Пантюхин Д.А. Коми-пермяцкий праздник Проллавер с обрядом Быкобой // Этнографическое обозрение. - 2012. - № 1. - С. 85101.

32. Поездка члена-сотрудника М.В. Малахова на Урал // Отчет Русского географического общества за 1881 г. / Сост. В.И. Срезневский. - СПб., 1882. - С. 35-38.

33. Полевые материалы. 2008 г. Кочевский район, д. Малая Коча, записано от Рисковой А.А., 1928 г.p., соб. Голева Т.Г.

34. Полевые материалы. 2008 г. Кочевский район, д. Малая Коча, записано от Рисковой Ф.Я., 1928 г.р., соб. Цыбин А.

35. Полевые материалы. 2019 г. Кочевский район, с. Кочево, записано от Исаевой Н.Н., соб. Голева Т.Г.

36. Рогов Н.А. Материалы для описания быта пермяков // Пермский сборник. - М., 1860. - Кн. 2. - Отд. 2. C. $1-127$.

37. Сабуров В. На скотском празднике (жертвоприношения пермяков) // Пермские губернские ведомости. - 1899. - № 219. - С. 2.

38. Садиков Р.P. Традиционные религиозные верования и обрядность закамских удмуртов (история и современные тенденции развития). - Уфа: Центр этнологических исследований УНЦ РАН, 2008. - $232 \mathrm{c}$.

39. Светлаков В., Светлакова Т. О необычном обряде // По Ленинскому пути. - 1963. - 24 марта. - С. 2.

40. Свизева $B$. Был ли быкобой? Большой репортаж из села, где проводят древний обряд жертвоприношения [Электронный ресурс] // 59.RU. - 2018. - 3 сент.. URL: https://59.ru/text/gorod/65340181/ (дата обращения: 19.03.2020).

41. Смирнов И.Н. Пермяки: Историко-этнографический очерк (Известия общества археологии, истории и этнографии при императорском Казанском университете. Т. 9. Вып. 2). - Казань: Типография Императорского ун-та, 1891. - 289 с.

42. Сорокин П. Старинный обряд у Зырян // Вологодские губернские ведомости. - 1848. № 30. - С. 339-401.

43. Список населенных мест Пермской губернии. Чердынский уезд. - Пермь: Электро-типография губернского земства, 1909. -219 с.

44. Справочная книга Пермской епархии на 1912 г. / Сост. П. Ершов. - Пермь: Электр. тип. Н-ков П.Ф. Каменскаго, 1911. $-289+20$ с.

45. Сущек Г. «Здесь нельзя отказываться». Как выжить на пиру в Большой Коче, или в погоне за Быкобоем [Электронный ресурс] // Звезда. 2018. 10 сентября. URL: https://zvzda.ru/articles/5365202acfaf (дата обращения: 18.06.2020).

46. Терюков А.И. Коллекция художника В.А. Плотникова в музее антропологии и этнографии имени Петра Великого // Радловский сборник. Научные исследования и музейные проекты МАЭ РАН в 2014 г. - СПб.: МАЭ РАН, 2015. - С. 148-152.

47. Формозов А.А. Уралец Малахов // Вопросы истории. - 1991. - № 4-5. - С. 171-174.

48. Харузин Н. Из материалов, собранных среди крестьян Пудожского уезда, Олонецкой губернии. M., $1889 .-73 \mathrm{c}$.

49. Черных A.B. Русский народный календарь в Прикамье. Праздники и обряды конца XIX - середины ХХ в. Ч. 1. Весна, лето, осень. - Пермь: Пушка, 2006. - 368 с.

50. Шестаков Я. Жертвоприношение пермяков-христиан в день Флора и Лавра // Этнографическое обозрение. - 1909. - № 4. - С. 32-36.

51. Шестаков И. Кочинская Ионо-Серафимовская женская инородческая обитель Чердынского уезда Пермской губернии. - Нижний Новгород: Типография И.А. Шелеметева, 1911. - 4 с.

52. Шестаков И. Верхнекамские инородцы. Опыт обозрения мероприятий земств Соликамского. Чердынского и Глазовского в целях культурного подъема камских инородцев. - Архангельск: Губернская Типография, 1912. - 15 с.

53. Шутова Н.И. Этнотерриториальные группы удмуртов: обряды и верования северных удмуртов. Ижевск: Издательство «Шелест», 2018. - 290 с.

54. Янович В.М. Пермяки. Этнографический очерк // Живая старина. - 1903. - Вып. I, II. - С. 52-171.

\title{
SACRIFICIAL RITE OF THE KOMI-PERMYAKS IN THE VILLAGE OF BOLSHAYA KOCHA
}

\author{
T.G. Goleva \\ Perm Federal Research Center UB RAS
}

The history of the sacrificial tradition of a Komi-Permian village is studied in the article. This tradition is known as «bykoboy» («slaughter of a bull») and is dedicated to the day of St Florus and Laurus. The tradition was distinguished by the amount of the sacrifice offered. The author clarifies 
that the holiday complex, in addition to the ritual of sacrifice and a common meal, included a prayer service, consecration of horses, races and a fair. The order and some conditions of the rituals would change from year to year. In particular, some changes were related to restrictions imposed by local authorities. Researchers' interest in the unusual tradition has led to its renown in wider circles. As a result, at the beginning of the XX century, church and community representatives began to pay special attention to the rite. In order to eradicate the sacrificial rituals, the clergy undertook a number of measures to enlighten the people. It is commonly believed that before the First World War the rite was banned. Subsequent historical events in the country contributed to the extinction of the tradition. At the turn of the XX-XXI centuries local residents revived the sacrificial ritual. The holiday ceremonial complex in the restored version slightly differs from the original tradition and has different symbolic meaning. The spread of information about the rite in our time has caused the emergence of negative statements, which led to the rejection of its public performance in 2018. Both in the past and in the XXI century, the rite of sacrifice performed the function of uniting the people, having conditioned the conduct of educational activities.

Keywords: Komi-Permyaks, sacrifice, Day of St Florus and Laurus, consecration of horses, I.Ya. Shestakov, N.N. Gusev, revival of tradition.

\section{Сведения об авторе}

Голева Татьяна Геннадьевна, кандидат исторических наук, старший научный сотрудник, Пермский федеральный исследовательский центр УрО РАН (ПФИЦ УрО РАН), 614900, г. Пермь, ул. Ленина, 13А; e-mail: golevat@yandex.ru 